\title{
MINING MARKETPLACES: EXPONENTS OF URBAN DEVELOPMENT OF MEDIEVAL SERBIA
}

\begin{abstract}
The paper follows the formation and the rise of mining marketplaces in Medieval Serbia and their contribution to the urban development of the country. In addition to mining marketplaces in Serbia, there were others as well, but the mining marketplaces experienced the highest rise and the greatest urban development. Present urban elements bear witness to the fact that that they were modern elements in those times. Their rise was discontinued, as well as the development of Medieval Serbian state in the middle of the $15^{\text {th }}$ century.
\end{abstract}

KEYWORDS: mining marketplaces, the Middle Ages, urban settlements, development, Serbia.

\section{MARKETPLACES AS SETTLEMENT TYPES}

Marketplaces are settlements characterized by trading which constantly took place, usually on certain days of the week. Because of the activity, which was not a prevailing one in the beginning and was running along with agriculture, such settlements were soon termed marketplace(s). It is interesting to notice that the word 'trg'

1 bozidar.zarkovic@pr.ac.rs

This paper was submitted on October $11^{\text {th }}, 2021$ and accepted for publication at the meeting of the Editorial Board held on November 16 ${ }^{\text {th }}, 2011$. 
(marketplace, square), which designates these settlements, comes from the Slavic word (tr'g'), which means goods for sale - exchange. This noun was used to designate goods meant for sale during the whole period of the Middle Ages, while in modern languages-Serbian and most of the other Slavic languages-new terms are in use now. In the Middle Ages, this term also came from Serbian to Albanian as 'trëgu' and is used today to designate a space where trade with goods takes place on certain days. For such a space, the Serbian language today uses the term 'pijaca' (market), which was obviously derived from the Italian language. Many other meanings connected with the process of trade i.e., the exchange of goods and means derived from the noun 'trg' (merchandise, goods). These are as follows: trade as a process and a walled trade as a process and walled space where exchange takes place, market - a synonym for trading, walled space, tradesman - a participant in the process of exchange, square - a place in the center of the settlement where there crossroads are and, finally, a type of settlement which is significantly characterized by trade. In the beginning, marketplaces as settlements in Medieval Serbia were not different from other surrounding settlements in the country, whereas their urban characteristic was determined, primarily, by its economy stream (Zarković, 2017, pp. 9-12, 157-162; Ćirković \& Mihaljčić, 1999, pp. 737-739; Mišić, 2010).

\section{FORMATION OF MARKETPLACES}

It is unknown when the first marketplaces were formed in Medieval Serbia. Their formation must have taken place, surely, in the early Middle Ages, even though they were first mentioned in the contract dating from 1186 signed between the Serbian Grand Župan Stefan Nemanja and Dubrovnik (Mošin et al, 2011, p. 47). Marketplace Drijeva, which was on the river Neretva, near its confluence into the Adriatic Sea, was mentioned on this occasion. Tradesmen from Dubrovnik were trading their goods using this marketplace in the western parts of Serbian lands and with Bosnia as well, which at that time was just starting to gain some independence.

Originally, they were formed in the places with favorable geographical area, on the crossroads and in the vicinity of buildings that could provide them with protection. Due to its favorable position, it attracted tradesmen selling their goods to occasionally 
gather together. Places where tradesmen occasionally met were not necessarily settlements but could be just some convenient spots. When the settlements were in Primorje, they were more of an urban character, while in the continental part of the country they were villages. Their shared characteristic was favorable geographical position on the crossroads. Importance of the marketplaces was noticed by Stefan Nemanja (1168-1196), and from his time onwards we could follow the phenomenon and the formation of some settlements of this type by using the data.

Lack of historical sources is the reason why the other marketplaces were not mentioned until 1198, when the Grand Župan Stefan Nemanja, monk Simeon at the time, founded the Monastery of Hilandar on the Holly Mount of Athos and donated it an estate which would support its existence. The estate was located at the very boundary of Southern Serbia, in the vicinity of Prizren (Zarković, 2007, pp. 209-223). It is named Hoča metochy in the documents consisting of 9 villages, four apiaries, two vineyards, 170 Vlach families (herdsmen) and income from Zeta (Zarković, 2002). Hoča, the largest village in metochy, was named after the monk Simeon who established a marketplace there (Mošin et al, 2011, p. 69). As it was formed within the monastery estate, it belonged to the church and was used by the church estate to sell its surplus of goods, but also to provide necessary merchandise. Access to the marketplace was free for everybody, not only for the inhabitants of that monastery estate and tradesmen. Tradesmen and their goods were protected. For all the goods that were not from the monastery estate but were sold there, taxes were paid, which as a rule belonged to the ruler. However, the ruler, in this case and all the other similar cases concerning the monastery estate, would renounce the contribution in favor of the church i.e., the monastery. The monk Simeon, the former Grand Župan Stefan Nemanja, decided to form a marketplace within the monastery probably because of the awareness of the significance and benefits such places brought both to the owner (the monastery) and the whole environment, and the country itself, as well. This example of Stefan Nemanja was followed by his successors on the Serbian throne which is why there was hardly any monastery with no marketplace within its estate. With the development of Serbia, monasteries began to get marketplaces outside their estates, primarily in the urban places. At the end of the independence of Medieval Serbian state, the church and monasteries frequently received monetary 
contributions from the marketplaces which were not under their authority, and were in the large urban centers. In that way, monasteries and the church received guaranteed income, instead of unreliable practice of tax collection, even from the marketplaces jeopardized by the Turks.

Similar to marketplaces, in churches and monasteries, both in the open space and in the rural and urban settlements, there were Panajurs (derived from Greek, $\pi \alpha v \alpha \gamma ı \rho \circ)$ which looked like fairs and trade fairs, but differed from them as they were organized during Church festivals (Ćirković \& Mihaljčić, 1999, pp. 488-489; Bojanin, 2005, pp. 138-139). They were held once or twice a year and were under the authority of the church or monastery which organized them. The aforementioned institutions collected the tax on the goods sold and punishment for the offences.

In Medieval Serbia-in its central part where the domestic influence was dominant, apart from the monastic ones-there were also marketplaces in the old ancient settlements, on the crossroads and caravan stations, and, of course, the mining marketplaces as well.

\section{FORMATION OF MINING MARKETPLACES}

Unlike monastery marketplaces which are formed by 'the rulers's grace' and intervention, mining marketplaces in Medieval Serbia are formed on different bases: spontaneously, like the old ancient places and village marketplaces, but conditioned by the ore resources. While formation of monastery marketplaces is related to agriculture and agricultural production, there is mining production and trade in mining in this matter. While agriculture was suitable for the population due to its simplicity, mining was a complex production process which required great knowledge and skill, both in finding and digging the ore out, even more so in its processing and obtaining the metal. Mining marketplaces in Medieval Serbia were created with the arrival of Saxon miners in the middle of the $13^{\text {th }}$ century. The Saxons came to Serbia during the reign of King Uroš I (Nemanjić), after a huge invasion of the Mongols which took place during 1241/42. There are two theories on the conditions under which they arrived but they are still a great puzzle: 1 . The Saxons accepted the invitation from King Uroš, who was, thus, following the example of Hungarian King Bela IV, who conducted colonization of his country with abandoned places due to the Mongol 
invasion; 2. The Saxons came to Serbia of their own free will, running away from the area of Transylvania in Hungary (Dinić, 2003, pp. 479-481). They decided so because of relatively unremarkable suffering of Serbia and because it was far from the center of the Mongol state. There is a possibility of a middle variant in which both parties came to the agreement that fulfilled the shared wish. This is confirmed by the privileges which Saxons got, and which could not be possible without a mutual consent. Whatever happened, with the Saxon arrival the formation of settlements with a different economy stream from the surrounding rural places began to occur.

Until then, it was not known that there were mining marketplaces (settlements) in Serbia, although the remains of the old mining works from the Roman times were visible and well known. This is also certified by the St Steven's Charter by King Milutin from 1316/ 17 , in which he mentioned 'the old holes'(Kovačević, 1890, p. 3). ${ }^{2}$ Those were the remains of the old mining work which flourished during the period between the $1^{\text {st }}$ and $3^{\text {rd }}$ century, during the Roman rule on the Balkan Peninsula (Ćirković et al, 2002, pp. 1117). It is interesting to note that the miners the Romans brought from Asia Minor made their contribution to the development of mining in Serbia during the ancient period (Dušanić, 1971, p. 242261). A similar situation occurred with the arrival of the Saxons in the mid- $13^{\text {th }}$ century. The Saxons made contribution to the mining production by introducing new methods of finding, digging, and melting the ore, as well as turning to the exploitation of precious metals, primarily silver. An important product of Serbian mines in the Middle Ages was also glam silver, silver with large admixtures of gold (argento de glama, argento indorato). These precious metals were dug out with led-zinc ores which Serbia had in large quantities.

The first mine and the first mining marketplace found in the documents was Brskovo on the river Tara (Kovačević, 1891, pp. 1-16). The first mention of the Saxons in this mine and the mining marketplace dates back to 1254 , but the latest studies have proved that the data on Brskovo as a marketplace is some ten years older, dating exactly back to the times when the Saxons came to Serbia (Sindik, 1981, pp. 53-66; Sindik, 1987, pp. 29-35; Sindik, 2008, pp. 305-309). Later on, the mention of the Saxons will always be related

2 The holes (rupe) are a medieval term which indicated the place where the mine was dug. The adverb old indicates the works from earlier Pre-Slavic time. 
to some of the mines; some of the mining settlements were even called Saxons in the documents. The reason for this is that the term lost its ethnic meaning in time and adopted the meaning of the profession. The term Saxon in the middle of the $14^{\text {th }}$ century certainly became a synonym for a miner, just as the terms Latin and Vlach became synonyms for tradesmen and herdsmen. Such terminology was also used after conquering of Serbia by the Turks, who called the old mining law 'Kanun-i-Sas' (Spaho, 1913, p. 134; Skarić, 1935, pp. 1-24; Skarić, 1939).

Places where the mining marketplaces were formed are contrary to the principles of the formation of village and monastery marketplaces; they were formed in the center of mining production, not in the favorable geographic places and the crossroads. Such places were on the mountains, often difficult to approach and with unfavorable climatic conditions. Yet, these places had the fastest development owing to their rich productivity.

\section{DEVELOPMENT OF MINING MARKETPLACES}

Another mining marketplace (the 'eternal second one' - as called by professor Hrabak) (Hrabak, 1984, p. 12), formed after Brskovo, was Rudnik, on the mountain bearing the same name. This mining marketplace was formed in the last two decades of the $13^{\text {th }}$ century, the first significant mention dates from 1293, and is related to the abdication of King Dragutin (1282) and dividing of the country with his brother Milutin (Dinić, 2003, pp. 557-558). Namely, King Dragutin thought that his fall from the horse and a seriously wounded leg was 'God's punishment' for his clash with his father and the violent arrival on the throne and decided that withdrawal from the throne would be a moral act. He was given the northern part of the country to govern which he enlarged, as Hungarian king, his father-in-law, gave him the territory all the way up to the Sava and the Danube rivers together with Belgrade. It seems that he brought a group of Saxons with him, who continued to deal with mining in Rudnik and also in the area of Podrinje (Petrović \& Bulić, 2009, pp. 43-62; Radičević \& Cicović, 2016, pp. 161-171; Radičević \& Ječmenica, 2016, pp. 9-19).

Relations between the two brothers, King Dragutin and King Milutin, went through different phases: from the cordial ones, followed by mutual aid in military campaigns against their enemies, to 
open conflicts. The state of economy in a divided country was developing independently of the political situation. This is certified by a number of new mines which appeared at the beginning of the $14^{\text {th }}$ century. They were mentioned in a letter to Pope Benedict XI from 1303 , in addition to the two already known mining marketplaces (Brskovo and Rudnik), Gračanica (i.e., Janjevo), Rogozno and Trepča (Theiner, 1968, p. 408). Besides, at the end of the second decade of the $14^{\text {th }}$ century, Novo Brdo was formed, the richest and the most significant mine and mining marketplace of Medieval Serbia, in the first half of the $15^{\text {th }}$ century and the whole Balkan Peninsula.

At that time, a number of mining marketplaces coincided with the number of the Roman Catholic parishes in the continental part of Serbia, which speaks volumes about the original inhabitants and miners, but also the fact that these settlements had been formed somewhat earlier, before the first mention and formation of the parishes. The veracity of the sources cited in relation to a number of mines is confirmed by the writing of an anonymous travel writer from the Western Europe who traveled across Serbia in 1308, as well as a file written by the archbishop of Bar (Guillaume Adam) from 1332 (Živković et al, 2013, p. 122; Mošin, 1977, pp. 597-620). ${ }^{3}$ In the descriptions they claim there were seven mines, i.e. five mines in Serbia. A continuous rise in the number of mines, from the first formation of the mine and mining marketplaces during the $14^{\text {th }}$ century and the first half of the $15^{\text {th }}$ century, was evident. Such growth and development tendency lasted until the middle of the 15 th century and fall of the Serbian lands under the Turkish power. About thirty mines were known in those times, two thirds of which were mentioned in the $15^{\text {th }}$ century (Ćirković et al, 2002, p. 96).

Newly-formed mines appeared in the same area where some other mining works had already been performed, either Medieval ones, or the remains of the mine digging from the Roman times. In that way mining areas (basins) which consisted of a large number of mines were formed. The most important mining area of Medieval Serbia is the Kopaonik one. This area is located on the mountain of

3 The paper from 1332 was attributed to Pseudo Brocard or Guillaume Adam. The second one used to be the Archbishop of Bar (1324-1341), "Primas of Serbia", under whose jurisdiction Roman Catholic parishes were in Serbia. That right was discredited by the Bishop of Kotor who complained to the Pope after which Climent VI wrote a letter that he sent to the emperor Dušan. On the struggle for jurisdiction under Roman Catholics of Serbia read more in Mitrović, 2011, pp. 289-305. 
Kopaonik and its surroundings. The very name of the mountain is derived from the verb 'kopati' (to dig) and designates a place where ore was dug. The name of this mountain in the documents written in foreign languages, which comes from the metal obtained by digging the ore, is Srebrena (Silver) mountain. In the documents written in Latin it is called Mons Argentum, in Italian it is Monte Argento, while in the Turkish language it is Gümiş Dag. Even today one part of this mountain is called Srebrenac in the Serbian language.

The second significant mining area was Novo Brdo. It was located somewhat south of Kopaonik area, in its immediate vicinity, which is the reason why a certain number of scientists considers both areas as one. The main marketplace and the mine were in Novo Brdo, a settlement inhabited by eight to ten thousand people. The wealth of the mine in the surroundings of Novo Brdo affected its faster development, which led to it becoming the largest mine and marketplace in the Balkans (Jovanović et al, 2004).

The third mining area was Podrinje and was located in the middle stretches of the river Drina, on both its riverbanks. This mine area was divided between Serbia and Bosnia, while the most important place in it was the town of Srebrenica with about 3.500 inhabitants, which belonged to the Serbian Despotate since 1411 (Kovačević-Kojić, 2010, pp. 19, 107). Although the mines in this area existed since the first half of the $14^{\text {th }}$ century, they became important only after the first Serbian-Turkish conflicts and the retreat of the population from the south towards the north.

Apart from these large mining areas, there were also some other ones which, due to small mines, borderline and peripheral position, distance from Primorje (Maritima) and the lack of historical sources were not observed enough. Those are, in the first place, areas south of Belgrade (from Avala to Rudnik) and in Eastern Serbia.

Each of the mentioned mining areas had several mines and marketplaces formed around the ore resources. However, it should be noted that there were marketplaces formed owing to their favorable position, but they developed owing to the mining production and trade. The most important one was Priština, a marketplace in the central part of the Kosovo plain, halfway between the Kopaonik and the Novo Brdo mining areas. This city, according to some parameters, kept pace with Novo Brdo and Srebrenica and had $2.000-2.500$ inhabitants (Zarković, 2019, p. 17). Similar to its neighboring town in the way of formation, the marketplace of Vučitrn also developed. 
One of the rare mining marketplaces which was deserted even before the fall of Serbian lands under the Turkish rule was Brskovo. Formation of new mines richer in ore, in more favorable places, in the vicinity of other mines and important settlements made Brskovo fall behind. That process lasted for a long time and ended with the abandonment of Brskovo which is mentioned as such in the document from 1433 (Ćorović, 1934, p. 48). The other mines and complete Serbian Medieval mining began to die out with the arrival of the Turks, although mining production did not cease immediately. Having realized the importance of mining, the Turks tried to adopt it to suit their needs and war economy. However, the decrease in the number of qualified miners affected it adversely and despite some motivating measures being taken, many mines reduced or completely stopped their production. Final termination of mine digging occurred during the Great Viennese War (16831689), after which a great number of Serbs emigrated and joined the Austrian army that retreated over the Sava and the Danube rivers.

\section{URBAN DEVELOPMENT}

The development of mining marketplaces was spurred and conditioned by economic activities in the places of their formation (Kovačević-Kojić, 1970, pp. 257-263; Kovačević-Kojić, 1972, pp. 167176). The main activity conducted by a large number of inhabitants of these settlements was digging the ore and its processing into metal. However, in order to make this activity successful a whole chain of accompanying professions was necessary. All of them made their contribution to the urban development of Medieval Serbia.

It is important to note that the urban development was not even in all parts of Medieval Serbia and could be divided into three zones: the coastal, in which towns with the Roman population and influence of Adriatic and Mediterranean towns - communes ${ }^{4}$ were prevalent; the southern one with towns which were formed and developed under the influence of Byzantium; and the central one where our Serbian influence is predominant (Dinić, 2003b, pp. 681-

4 Owing to the similarities in the development, H. Pirenne named these towns Mediterranean commonwealth (Pirenne, $1974^{3}$, p. 4). 
682). Mining marketplaces were formed and developed almost exclusively in the central zone, whereas they could not be found in the coastal one, and only few of them were found in the southern zone, which made their influence on urban development in these parts almost non-existent. In the southern zone, only the marketplace of Kratovo stood out. Although its beginnings go back to the $14^{\text {th }}$ century, it became noticeable only during the Turkish rule, probably because it was the first mine which fell into their hands (1395). ${ }^{5}$

It is necessary to emphasize one more fact significant for the urban development of Medieval Serbia. There was an opinion spread among experts that Medieval Serbia had no urban (town) settlements. The reasons for such an opinion were manifold, and the main one was the fact that the Serbs on their arrival to the Balkan Peninsula did not move to the towns they conquered from Byzantium. They began to decay, which is confirmed by extraordinarily developed terminology in the Serbian language used for abandoned settlements, which affected topography as well-on the territory of Serbia there are more than 140 identified toponyms for the abandoned settlements (Živković, 2000, pp. 116-117). In addition, specific terminology present in the old Serbian language should be mentioned. Namely, the term for a town, which in modern Serbian language designates a larger urban settlement had a completely different meaning in the Middle Ages. This term comes from the Slavic root - from the noun 'ograda' (fence) and denoted a walled space in the Middle Ages which was used to designate a fortress and fortified (fenced) settlement, but also meant a monastery with large walls, even corral for livestock (Zarković, 2017a, p. 429).

Such an opinion was conditioned by the situation from the beginning of the $19^{\text {th }}$ century - from the times of formation of modern Serbian state for its fight for liberation from the Turks. The reformer of the Serbian language, an important collector of the folk sayings and the participant of the First and Second Serbian uprising against the Turks, Vuk Karadžić noted down that the Serbs lived in villages, while the Turks lived only in towns (Ćirković, 1992, p. 14). The nineteenth century gave birth to many scientific disciplines, and in that time in Serbia, after a longer break, history was renewed as a science. Vuk Karadžić's claim which, generally speaking, was true as it reflected the then state formed during the centuries of

5 Matschke (2002, p. 119) does not believe in the possibility that enthusiasm of mining in the Balkans after the arrival of Saxons was also in the Byzantium. 
Turkish occupation, influenced the above-cited opinion. It is, however, only partly true; the Serbs did not settle in the towns on their arrival and that lasted only for a couple of centuries but did not last throughout the whole of the Middle Ages. This is confirmed by the three charters by the Emperor Basil II the Bulgar Slayer (Boulgaroktonos) from 1019-1025 in which he names all large town settlements by their Slavic name, rejecting their former ancient names. Thus, Basil II refers to ancient Viminacium as Braničevo, Singidunum - Belgrade, Nais - Niš, Arsa - Ras, Margum - Moravisk, Horeu Margi - Brodarisk, etc. (Novaković, 2003, pp. 82, 84-85, 88-89, 98; Ostrogorski, 1955, pp. 57, 61-63, 66-67). It is evident that the Slavic names occurred due to the changes of ethnic structure in the towns. In some cases, noun changes are minor and came as a result of adaptation of the previous name (Niš, Ras), in other cases they were drastically changed and bore no resemblance to the previous, ancient name (Beograd, Braničevo). Vuk Karadžić's opinion reflects the situation from the times under the Turkish rule, when the Serbs were expelled from the towns into the villages.

The opinion on the absence of the towns in the continental part of the Balkans can be found in the writings of some Medieval travel writers as well. Thus, Anonym in his travel writing from 1308 says: "Preterquam in Maritima Regione dicta, ubi sunt sex ciuitates, in toto regno prefato non est aliqua ciuitas (italics B. Z.). Sunt tamen in eo multa castra, fortalicia et magne uille de trecentis et quadringentis domibus de lignis et asseribus edificatis sine aliqua clausura" (Živković et al, 2013, p. 122). The same opinion on the absence of towns in the continental part of Serbia came from the East and was uttered by the Byzantine pretender to the emperor's throne John Cantacuzene VI, who in 1342 met the Serbian King Dušan. The meeting was held in Priština, where there was one of the royal courts for Serbian rulers. Priština, which was one of the three largest towns in Serbia, was called $\kappa \dot{\omega} \mu \eta$ - unfortified village by Cantacuzene (Barišić \& Ferjančić, 1986, p. 387). Such an attitude of the travel writer from the west and emperor's pretender from the East illustrates unequal criteria for defining the towns, that is what they saw in Serbia was not in accordance with the appearance of towns in their countries.

Although only partly true, as it reflects the situation in the times before the forming of the Serbian state, or the personal attitude, the opinion on the absence of urban settlements in Serbia was accepted and has prevailed to this day in certain individuals and in some historiographies (Hösch, 2008, p. 25). However, this does not 
correspond to the truth. Formation of some thirty marketplaces during the two centuries (middle of the $13^{\text {th }}$ to middle of the $15^{\text {th }}$ century) illustrates that those settlements had a dynamic development which made significant contribution to urbanization. Although these settlements, most often, did not look like the towns from the west or Byzantium, there is no doubt that they had urban characteristics. In order to avoid falling into the trap of defining towns, we started with something that clearly differentiates urban settlements from the rural ones, an economic orientation. Whereas in villages the only profession is agriculture (apart from rare crafts), there are mining, trade, crafts, and various offers and services in the urban places (Kovačević-Kojić, 2007, pp. 337-342). In such a classification, mining marketplaces are exclusively urban settlements.

Their urban character is confirmed by other properties such as: number of citizens, their multinational, multicultural, multireligious character, specific administrative organization, monetary economy, number and variety of professions, and so on.

The exact number of inhabitants living in the settlements in Medieval Serbia is not known. However, one could make assumptions regarding the number of inhabitants for some of them. Calculations done on the basis of the number of houses and their size determined that the largest settlements were the mining marketplaces Novo Brdo, Srebrenica, and Priština. We have already said that Priština was not a mining settlement, but that it used to be a marketplace where trading of mining products took place. Settlements whose development was influenced by their rulers' privileges and interventions, such as monastery marketplaces or the capitals such as Kruševac, Belgrade, and Smederevo, did not succeed in reaching that level of development. Even some old towns inherited from Byzantium, such as Prizren, Lipljan, and Niš, could not keep up with the development of mining marketplaces and began to die out, as tradesmen avoided them.

Those defining traits of modern urban settlements-a variety of population, both in terms of ethnicity and culture, education, religion and many other aspects-were present in those mining marketplaces (Zarković, 2014, pp. 193-206). The original inhabitants were Saxon miners, but were soon joined by tradesmen from numerous maritime communes: Kotor, Bar, Ulcinj, Budva, Ston, Split, and particularly Dubrovnik. There were inhabitants from Italian, Hungarian, Greek, Bulgarian, and naturally Serbian towns, who 
quickly took over mining and smelting works from the Saxons. One part of the Serbs started trading and tried to gain Dubrovnik citizenship, hence in their documents we find that they are 'those who call themselves inhabitants of Dubrovnik'. From the third decade of the $15^{\text {th }}$ century a large number of Greeks could be found in mining marketplaces. They had to run away from the Turkish invasion and found refuge in Serbia. They were supported by Irina, wife of the despot Đurađ Branković (ruled 1427-1456), who was descended from the famous Greek family of Kantakouzenos. A shared characteristic of all the inhabitants of mining marketplaces, regardless of their different ethnic origin, is urban solidarity and identification with a community they were part of. It is recorded that Dubrovnik citizens fiercely defended Serbian towns from Turkish raids, Novo Brdo, in the first place. The best example is an inhabitant of Novo Brdo, Martin Segon, writer and theologian from Bologna, the last bishop of Ulcinj, who was aware of his origin and the position of the Roman Catholic Bishop, and who wrote a tractate on the ways the West should attack the Turks (Quibus itineribus Turci sint aggrediendi). ${ }^{6}$

The characteristic of Mediterranean communes and the towns of Western Europe is autonomy. In Serbia, the towns did not have the autonomous status, but certain autonomy was present in the mining marketplaces. Autonomy was reflected in the fact that these settlements had certain administration from their very founding. In the administration of the marketplace, apart from representatives of the central authorities (kefali, duke) there were also local representatives. The most important one was the prince, who was chosen from the most distinguished inhabitants, and was approved of by the ruler. The prince had, along with other local clerks, certain administrative and judicial functions. An important authority and distinguished representative of the local self-government was the committee of purgar made up of 12 members. The very term 'purgar' is not of Slavic origin but comes from German Bürger. In Serbian documents, it is translated as citizens, and in the Italian ones as borghesani. A member of the local self-government was 'putal' i.e., 'telal' who announced important news in the marketplace.

Towns in the West received charters of liberty from their rulers. We are not familiar with the fact that Serbian towns were awarded with a similar document by their rulers. There is an indication that

$6 \quad$ Read more in Pertusi, 1981. 
Belgrade had a charter, but it is not known, nor are its provisions. Town charters were mentioned during the reign of Emperor Dušan but only those for the cities which he conquered from Byzantium. It is considered that he only verified the value of the charters already awarded by the Byzantine rulers. The most similar to town charters is The Law of the Novo Brdo town, which despot Stefan Lazarević, together with The Law on Mines, awarded to Novo Brdo in 1412. While The Law on Mines was a technical law which regulated the production process in the mines and smelters, The Law on Novo Brdo proscribes obligations and rights of the inhabitants and the management of the mining marketplace. In older literature, this act was called the statute and was related to similar acts of maritime communes. However, this was a law, as the title says, not a statute. The difference lies in the fact that the statute is a reflection of autonomy which the citizens themselves adopt at the assembly, while the law is established by the ruler, who "with his mercy" passes it and is able to limit certain rights. Thus, The Law on Novo Brdo, although it made a breakthrough in terms of autonomy, was not like that in reality. The laws of other marketplaces have not been preserved, nor is it known that they ever existed, except in the case of Srebrenica, but it is not preserved and its articles are also unknown.

The urban character of mining marketplaces is confirmed by the presence of a considerable number of craftsmen living in them, but also in their immediate vicinity. All of them produced craft products intended for the market of the mining marketplace. Thus, in Novo Brdo during the thirties of the 15th century, there were 54 craftsmen in total and 28 more in the surroundings. The most numerous craftsmen were blacksmiths (12 in the settlement itself and 11 more in the surroundings), then tailors (14-6), goldsmiths (4-4), shoe makers (5-3), furriers (4-1), butchers (5-0), and others (Kovačević-Kojić, 2007, p. 374).

A similar situation was also recorded in other mining marketplaces, albeit with a smaller number of craftsmen. Thus, in Srebrenica, in a longer period from 1413 to 1459 , there were 70 goldsmiths, 47 tailors, 21 clothiers, 14 butchers, 12 furriers (Kovačević-Kojić, 2010, pp. 59, 65-66). In Trepča, the presence of 42 craftsmen, mostly goldsmiths (27) and furriers (5), was recorded (Milutinović, 1993, p. 236). Almost the same number was recorded in Priština - 41 craftsmen, the most numerous of whom were goldsmiths (18), furriers (8), tailors (6), bakers (3), carpenters (2), and others (Kovačević-Kojić, 2007, p. 76). These are only recorded craftsmen, but cer- 
tainly there must have been other craftsmen, who never made their mark in the documents. A large number of goldsmiths is noticeable which speaks volumes about the trade of precious metals.

Mining production included a great number of various professions, which required good training. Certain professions required literacy, such as: urborar (collectors of 'urbor' - ruler's taxes in the mines), 'hutman' (the leader of a group which exploits ore), he was helped by a dijak (a scribe), custom officer (tax collector on the sold goods), tradesmen, nomic (scribes, notaries), and others. There were also schools, private and parish owned, and there was more than one vicar. That is why the mining marketplaces became centers of literacy, too. In Serbia, such an activity was exclusively in the domain of the church before the second half of the $14^{\text {th }}$ century. Writers began to spend more time in the marketplaces. Thus, in Novo Brdo, in the first half of the $20^{\text {th }}$ century, Dimitrije Kantakuzene, Vladislav Gramatik, Martin Segon, Konstantin Mihailović wrote their works (Zarković, 2015, pp. 957-960, 964).

Life in the mining marketplaces involved problems that persisted in urban settlements. A great number of inhabitants required a considerable quantity of food, thus it occasionally lacked. In order to solve this issue, the town authorities made certain decisions. It was proscribed that the miners, because of their importance for the life of the town should have priority in terms of supplies. The prince was monitoring the sale and nobody could purchase anything unless the miners were supplied with food (Radojčić, 1962, p. 53). The price for most important life essentials was set by law.

Although these measures were effective, there were still poor people in the marketplaces. The widows found themselves in the worst situation, thus The Law of Novo Brdo had a regulation on certain benefits for this category. One part of the inhabitants dealing with trade did not have the initial capital and borrowed from the lender. Some of them were not able to return the borrowed sum, and were taken to prison and pushed into debt slavery. When this phenomenon grew rampant, despot Đurađ proscribed a regulation in 1432 prohibiting the creditors from taking more than one third of debtors' income. At the same time, Dubrovnik government advised its citizens acting as creditors to be humane to debtors and to avoid their public arrest and imprisonment (Spremić, 1994, p. 685; Zarković, 2016, pp. 45-55).

An increase in the population, gruesome living conditions, unhealthy vapors from the mines and the smelters caused people's 
health to deteriorate. It seems that the town management kept people under increased surveillance during major infection epidemics, but it is not known if they spread among the population of mining marketplaces to a greater extent. Still, health problems were occurring. Thus, the tradesmen from Srebrenica in 1435 complained to despot Đurad about a bad health situation blaming numerous smelters for it. They claimed that they were the cause of death of many good people and asked for the smelters to be removed out of the town (Kovačević-Kojić, 2007d, p. 219).

Owing to the development of mining marketplaces, certain Serbian Orthodox metropolitan churches were based in them. Thus, the old Lipljan diocese, the heiress of ancient Ulpiana, was moved to the monastery of Gračanica, and then to Novo Brdo (Jovanović et al, 2004, p. 124; Janković, 1985, p. 187). Emperor Dušan's Code in its article 7 allowed the presence of the proto-vicars in all the marketplaces and towns. They were the elders over the other vicars of the Orthodox Church and ensured that there was no converting of Orthodox believers into the Roman Catholics. Proto-vicars were present in the marketplaces of Novo Brdo, Trepča, Priština, Skopje, Kratovo, and Štip. In the mining marketplaces, there were also Roman Catholic parishes over which the Archbishop of Bar and the bishop of Kotor disputed before the Pope. Regarding this matter, Pope Clement VI wrote to the Serbian Emperor Dušan at the beginning of 1346.

CONCLUSION Mining marketplaces in Medieval Serbia are urban settlements which experienced the highest and fastest development. In the course of the two centuries of their existence (middle of the $13^{\text {th }}$ to middle of the $15^{\text {th }}$ century) their development was speeding up. Economic conditions, that is, ore resources and presence of precious metals, made their contribution to it. Development of these settlements was accelerating even during daily wars with the Turks in the course of the first half of the $15^{\text {th }}$ century. The fall of Serbia under the Turkish power put an end to this development, which is defined using a phrase 'a discontinued rise'. During their existence, mining marketplaces surpassed other urban settlements in many respects. Urban elements experienced the highest form of their development in the marketplaces themselves. Life in these settlements did not differ from living conditions in other urban places in the Balkans. However, the elements of autonomy which began to 
develop did not reach the level which free towns in Western Europe had. That situation was described as an 'unrealized autonomy'. slavije.t. VI, Barišić, F., Ferjančić, B. (ed), Beograd: Vizantološki institut SANU.

Kovačević, Lj. (1890). Svetostefanska hrisovulja. Kovačević, Lj. (ed). Beograd: Srpska kraljevska akademija.

Mošin, V. (ed) (1977). Directorium ad passagium faciendum per Phillipum regem Franciae in terram sanctam anno 1332. In: Spomenici za srednovekovnata i ponovata istorija na Makedonija, t. II, 597-620.

Mošin, V., Ćirković S, \& Sindik, D. (2011). Zbornik srednjovekovnih ćiriličkih povelja i pisama Srbije, Bosne i Dubrovnika. Beograd: Istorijski institut.

Ostrogorski, G. (1955). Vizantijski izvori za istoriju naroda Jugoslavije. t. I, Ostrogorski, G. (ed). Beograd: Vizantološki institut SANU.

Radojčić, N. (1962). Zakon o rudnicima despota Stefana Lazarevića. Beograd: Narodno delo.

Theiner, A. $\left(1968^{2}\right)$. Vetera monumenta historica Hungariam sacram illustrantia. t. 1, Ab Honorio PP. III usque ad Clementem PP. VI (1216/1352). Osnabrück: Otto Zeller.

Živković, T., Petrović, V., \& Uzelac, A. (2013). Anonymi Descriptio Europae Orientalis. Anonimov opis istočne Evrope. Beograd: Istorijski institut.

\section{REFERENCES}

Bojanin, S. (2005). Zabave i svetkovine u srednjovekovnoj Srbiji od kraja XII do kraja XV veka. Beograd: Istorijski institut, Službeni glasnik.

Ćirković, S. (1992). Urbanizacija kao tema srpske istorije. In: Kalić, J, Čolović, M. (ed), Socijalna struktura srpskih gradskih naselja (XII - XVIII vek). Smederevo - Beograd: Muzej Smederevo, Odeljenje za istoriju Filozofskog fakulteta u Beogradu, 9-19.

Ćirković, S., Kovačević-Kojić, D., \& Ćuk, R. (2002). Staro srpsko rudarstvo. Novi Sad: Prometej.

Ćirković, S. \& Mihaljčić, R (1999). Leksikon srpskog srednjeg veka. Beograd: Knowledge.

Ćorović, V. (1934). Brskovo. Glasnik Geografskog društva, 20, 40-49.

Dinić, M. (2003). Za istoriju rudarstva u srednjovekovnoj Srbiji i Bosni. In: Dinić, M. Iz srpske istorije srednjega veka. Beograd: Equilibrium, 455-668.

Dinić, M. (2003). Gradovi u srednjovekovnoj srpskoj državi. In: Dinić, M. Iz srpske istorije srednjega veka. Beograd, 679-685. 
Dušanić, S. (1971). Novi Antinoev natpis i Metalla municipii dardanorum. Živa antika, 21/1, 242-261.

Janković, M. Episkopije i mitropolije srpske crkve u srednjem veku. Beograd: Istorijski institut, Narodna knjiga.

Jovanović, V., Ćirković, S., Zečević, E., Ivanišević, V., \& Radić, V. (2004). Novo Brdo. Beograd: Republički zavod za zaštitu spomenika kulture.

Kovačević, Lj. (1891). Trg Brskovo i župe Brskovska i Ljuboviđska. Glas SKA, 30, 1-16.

Kovačević-Kojić, D. (1972). Le développement économique des aglomérations urbaines sur le territoire actuel de la Yougoslavie du XIIIe au XVe siècle. Athènes, Actes du IIe Congrès international des études du Sud-Est européen. t. II, 167-176.

Kovačević-Kojić, D. (1970). Uloga rudarstva u privrednom razvoju gradskih naselja Srbije i Bosne tokom prve polovine XV vijeka. Godišnjak Društva istoričara $\mathrm{BiH}, 18,257-263$.

Kovačević-Kojić, D. (2007a). Odnos rudarskih centara i sela u Srbiji i Bosni u srednjem vijeku. In: Kovačević-Kojić, D. Gradski život u Srbiji i Bosni. Beograd: Istorijski institut, 337-342.

Kovačević-Kojić, D. (2007b). Prilog proučavanja zanatstva u Novom Brdu i okolini. In: Kovačević-Kojić, D. Gradski život u Srbiji i Bosni (IX - XV vijek). Beograd: Istorijski institut, Beograd 2007, 371-380.

Kovačević-Kojić, D. (2007c). Priština u srednjem vijeku. In: Kovačević-Kojić, D. Gradski život u Srbiji i Bosni (XIV-XV vijek). Beograd: Istorijski institut, 57-91.

Kovačević-Kojić, D. (2007d). Zdravstvene prilike u srednjovekovnoj bosanskoj državi. In: Kovačević-Kojić, D. Gradski život u Srbiji i Bosni (XIV-XV vijek). Beograd: Istorijski institut, 219-224.

Kovačević-Kojić, D. (2010). Srednjovjekovna Srebrenica, XIV - XV vijek. Beograd: SANU.

Matschke, K.P. (2002). Mining. In: Laiou, A. E. (ed): The Ecomonic History of Bizantium: From the Seventh trough Fifteenth Century, Washington, Dumbarton Oaks, 115-120.

Milutinović, B. (1993). Dubrovčani u Trepči. Zbornik radova Filozofskog fakulteta u Prištini, 31-32, 211-241.

Mišić, S. (ed.) (2010). Leksikon gradova i trgova srednjovekovnih srpskih zemalja, prema pisanim izvorima. Beograd: Zavod za udžbenike.

Mitrović, K. (2011). Sukob barskog arhiepiskopa i kotorskog episkopa oko jurisdikcije nad katoličkim parohijama u srednjovekovnoj Srbiji. In: Spomenica Sime Ćirkovića. Beograd: Istorijski institut, 289-305.

Mošin, V., Ćirković, S., \& Sindik, D. (2011). Zbornik srednjovekovnih ćiriličkih povelja i pisama Srbije, Bosne i Dubrovnika. Beograd: Istorijski institut. 
Novaković, S. (2003). Ohridska arhiepiskopija u početku XI veka. Hrisovulje cara Vasilija II 1019. i 1020. godine. In: Novaković, S. Spisi iz istorijske geografije. Beograd: Zavod za udžbenike i nastavna sredstva, 59-102.

Pertusi, A. (1981). Martino Segono di Novo Brdo Veskovo di Dulcigno: Un umanista serbo-dalmata del tardo Quattrocento: Vita e opera. Roma: Instituto storico italiano per il medio evo.

Petrović, V. \& Bulić, D. (2009). Problem ubikacije srednjovekovnog Rudnika. Istorijski časopis, 58, 43-62.

Pirenne, H. (1974³). Medieval cities. Their origins and the revival of trade. Princeton: Princeton University Press.

Radičević, D. \& Cicović, A. (2016). Tipar kneza Lazara sa Rudnika. Starinar, 66, 161-171.

Radičević, D. \& Ječmenica, D. (2016). Natpis na rudničkom tiparu kneza Lazara. Natpisi i zapisi, 2, 9-19.

Sindik, D. (1981). Pontifikal Kotorske biskupije u Lenjingradu. Istorijski časopis, 31, 53-66.

Sindik, D. (1987). Marginalia Catharensia. Istorijski časopis, 34, 29-35.

Sindik, D. (2008). O prvom pomenu Brskova. Istorijski časopis, 56, 305-309.

Skarić, V. (1935). Stari turski rukopis o rudarskim poslovima i terminologiji. Spomenik SKA, 79, 1-24.

Skarić, V. (1939). Staro rudarsko pravo i tehnika u Srbiji i Bosni. Beograd: SKA.

Spaho, F. (1913). Turski rudarski zakoni. Glasnik Zemaljskog muzeja u Sarajevu, 25, 1-2, 1-60.

Spremić, M. (1994). Despot Đurađ Branković i njegovo doba. Beograd: Srpska književna zadruga.

Hrabak, B. (1984). Rudnik pod Šturcem i njegova Dubrovačka naseobina. Zbornik radova Narodnog muzeja Čačak, 14, 5-86.

Hösch, E. $\left(2008^{5}\right)$. Geschishte der Balkanländer. Von der Frühzeitbis zur Gegenwart. München, C. H. Beck.

Zarković, B. (2002). Hotačka metohija hilandarskog vlastelinstva u srednjem veku. Prvi hilandarski posed u Srbiji. Kosovska Mitrovica - Leposavić: Filozofski fakultet, Institut za proučavanje kulture Srba.

Zarković, B. (2007). o južnim granicama Srbije u vreme vladavine Stefana Nemanje. Baština, 23, 209-223.

Zarković, B. (2015). Karakteristike pismenosti u gradovima srednjovekovne Srbije. In: Milenović, Ž, Baščarević, S. (ed), Nastava i nauka u vremenu i prostoru. Leposavić: Učiteljski fakultet, 951-966.

Zarković, B. (2014). Srpski gradovi prve polovine XV veka - centri multikulturalnosti. In: Jovanović, B, Vilotijević, M. (ed), Uloga obrazovanja i vaspi- 
tanja u razvijanju humanističkih, interkulturalnih i nacionalnih vrednosti, Kosovska Mitrovica - Beograd: Filozofski fakultet Univerziteta u Prištini, Srpska akademija obrazovanja, 193-206.

Zarkovič, B. (2016). Nekotorye sovremnnye эkonomičeskye javlenija, svořstvennye srednevekovoĭ Serbii. [on Russian] In: Antipov, S. T. et al, Sovremennye problemy gumanitarnyh i obščestvennyh nauk, Serija „Duhovnaja žizn` obščestva i čeloveka: istorija i sovremennost “ “, vypusk 3 (11), Voronež $(\mathrm{Ru})$, Voronežskii gosudarstvennyi universitet inženernyh. tehnologii, 45-55.

Zarković, B. (2017). Trgovi i urbanizacija Srbije u srednjem veku. Kosovska Mitrovica: Filozofski fakultet.

Zarković, B. (2017a). Svetostefanska hrisovulja kao izvor za proučavanje urbanizacije srednjovekovne Srbije. In: Mišić, S. (ed), Srpska kraljevstva u srednjem veku, Beograd, Niš, Kraljevo, Univerzitet u Beogradu - Filozofski fakultet, Univerzitet u Novom Sadu - Filozofski fakultet, Univerzitet u Nišu - Centar za vizantijsko-slovenske studije, Grad Kraljevo, 417-434.

Zarković, V. (2019). Priština na razmeđi vekova. Leposavić, Institut za srpsku kulturu.

Živković, T. (2000). Sloveni i Romeji. Slavizacija na prostoru Srbije od VII do XII veka. Beograd: Istorijski institut.

\section{БОЖИДАР В. ЗАРКОВИТ}

УНИВЕРЗИТЕТ У ПРИШТИНИ СА ПРИВРЕМЕНИМ СЕДИШТЕМ

У КОСОВСКОЈ МИТРОВИЦИ, ФИЛОЗОФСКИ ФАКУЛТЕТ

КАТЕДРА ЗА ИСТОРИЈУ

РЕЗИМЕ

РУДАРСКИ ТРГОВИ - НОСИОЦИ УРБАНОГ РАЗВОЈА СРЕДЊОВЕКОВНЕ СРБИЈЕ

Урбани развој средњовековне Србије значајније је започео средином XIII века доласком рудара Саса. Њихово насељавање у Србији још увек није најјасније, дилема је да ли су дошли на позив краља Уроша I (Немањића) или су у Србији нашли уточиште

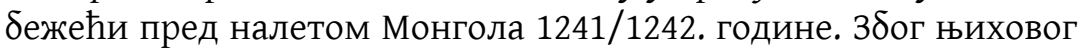
умећа у експлоатацији руде од српских владара су добили привилегије, које су им омогућиле да слободно живе, исповедају своју веру, уживају судски имунитет у међусобним споровима и имају сопствену организацију у местима која насељавају. Долазак Саса поклапа се са поменом првих рудника у Србији. Убрзо број рудника значајно расте, а привреда у Србији доживљава на- 
предак. Знатан привредни успон осетио се за време владавине краља Милутина (1282-1321) и стално је напредовао, све до пада српских земаља под турску власт средином XV века.

Доласком у Србију Саси се колективно насељавају у близини постојећих насеља и трагова старог рударства, које је на овим просторима имало значајно место још у време римске владавине. У Србији се и пре доласка Саса вадила руда, али примитивним методама. Допринос Саса био је у томе што су донели напредне методе експлоатације руде и што су рударство усмерили према племенитим металима. Појачана рударска експлоатација довела је до отварања нових рудника и рударских насеља и до ширења постојећих. Тај процес је захтевао укључивање нове радне снаге, која је долазила из локалног српског становништва. Временом термин Сас је изгубио етничко значење и њиме се означавају сви они који су укључени у рударску производњу. На исти начин насеља у којима су у почетку живели претежно Саси, а временом и рудари других нациналности, почињу да се називају саским. Ова насеља у почетку се мало разликују од околних села, али документа их бележе као саске градове, иако изгледом не личе на урбана насеља Западне Европе или Византије. Овим термином се означавају рударска насеља, која се називају градовима због тога што се разликују од оних у окружењу. Разлика у односу на друга насеља била је у томе што су имала другачију административну управу и привредно усмерење у односу на аграрно окружење. Ова насеља имала су најбржи урбани развој у средњовековној Србији. Осим рудара различитих специјалности у њих се све више усељавају и људи других, пратећих занимања, пре свега бројне занатлије, али и радници услужних и разних помоћних делатности. Сви они живе по правилима својих есна$\phi а$, што је требало ускладити ради бољег функционисања насеља.

КљУчнЕ РЕчи: рударски тргови; средњи век; градска насеља; развој; Србија.

Овај чланак је објављен и дистрибуира се под лиценцом Creative Commons Ауторство-Некомерцијално Међународна 4.0 (CC BY-NC 4.0|

https://creativecommons.org/licenses/by-nc/4.0/).

This paper is published and distributed under the terms and conditions of the Creative Commons Attribution-NonCommercial International 4.0 licence (CC BY-NC 4.0 | https://creativecommons.org/licenses/by-nc/4.0/). 